\title{
Frequency converter-based monitoring, diagnostics and control system for artesian well pumps
}

\author{
T.A. Aliev*, A.M. Abbasov, G.A. Guluyev, As.H. Rzayev, Y.G. Aliyev \\ Institute of Control Systems of Azerbaijan National Academy of Sciences, Baku, Azerbaijan
}

\begin{tabular}{|c|c|}
\hline A R T I C L E I N F O & A B S T RA C T \\
\hline $\begin{array}{l}\text { Article history: } \\
\text { Received 09.09.2021 } \\
\text { Received in revised form 23.09.2021 } \\
\text { Accepted 04.10.2021 } \\
\text { Available online } 29.12 .2021 \\
\text { Keywords: } \\
\text { Variable frequency drive } \\
\text { Energy-saving equipment } \\
\text { Frequency converter } \\
\text { Subartesian well } \\
\text { Asynchronous motor } \\
\text { Pump } \\
\text { Smooth control }\end{array}$ & $\begin{array}{l}\text { The article highlights the relevance of energy saving problems on } \\
\text { a global scale and the need to regulate by state laws the } \\
\text { production and application of frequency converters, which allow } \\
\text { to reduce the energy consumption of asynchronous motors by 30- } \\
60 \% \text { depending on the load as a result of the International } \\
\text { Energy Agency's targeted energy policy. Different characteristics } \\
\text { of controlling the asynchronous motor, which is the main } \\
\text { transmission of artesian well pumps, with Straight and } \\
\text { Frequency Transducer (Variable Frequency Transmission) from } \\
\text { the power grid are compared; the principles of energy-saving } \\
\text { frequency converter (FC) with pulse-width modulation, } \\
\text { increasing the power factor (PF-Power Factor) are interpreted, } \\
\text { as well as the principle of operation and bloc explained, } \\
\text { including the principle of operation and the block diagram. The } \\
\text { authors report on the positive results of the work carried out in } \\
\text { the oil fields by the Institute of Control Systems of ANAS together } \\
\text { with Cybernetics SDB on the identification of energy-saving } \\
\text { sources and finding ways to save energy. The article } \\
\text { substantiates the urgency of creating a frequency converter- } \\
\text { based monitoring, diagnostic and control system for subartesian } \\
\text { well pumps. At the same time, the surface and underground } \\
\text { equipment of subartesian wells is studied, technical requirements } \\
\text { for an automated control system for early diagnosis and optimal } \\
\text { control of their technical condition are formulated, and the } \\
\text { structure of a new SCADA system is proposed. A comparative } \\
\text { analysis of the operation of the artesian well engine directly and } \\
\text { by the FC-based Artesian Well Smooth Control Station (AWSCS) } \\
\text { proposed in the system is given for different cases. }\end{array}$ \\
\hline
\end{tabular}

\section{Introduction}

The economic development of the world steadily increases the demand for electricity. Meeting the growing energy demand, energy independence, efficient economic development, environmental protection are the main areas of activity of developed countries.

For this reason, the International Energy Agency was established in France on November 18, 1974, with 28 member countries (US, Germany, Australia, Austria, Belgium, South Korea, Czechoslovakia, Denmark, Estonia, Finland, France, England, Ireland, Italy, Spain, Sweden,

\footnotetext{
${ }^{*}$ Corresponding author. (G.A. Guluyev), asifrzayev48@gmail.com (A.H. Rzayev), aliyevyaver@gmail.com (Y.G. Aliyev).

E-mail addresses: telmancyber@ rambler.ru (T.A. Aliev), pr.dr.abbasov@gmail.com (A.M. Abbasov), scb_06@mail.ru 
Switzerland, Canada, Luxembourg, Hungary, The Netherlands, Norway, Poland, Portugal, Slovakia, Turkey, Japan, New Zealand, Greece). Russia joined the organization in 1994, China in 1996 and India in 1998. Targeted energy policy of the International Energy Agency is called 3E [1]:

Energy security;

Economic development;

Environmental protection.

Over the years, the rising cost of electricity and the high demand for it have created a desire to reduce energy consumption in many industrial and commercial enterprises.

The issue of energy saving strongly calls for efficient, waste-free operation of all enterprises in each country, as well as in Azerbaijan.

More than $60 \%$ of the world's electricity is consumed by electric motors and a lot of money is spent on electric energy. 70-80\% of electric motors are asynchronous motors, and most of them are used in energy-saving pumping, compressor, ventilation systems (HVAC - Heating, Ventilating, Air Conditioning).

Given that electric motors are a potential energy-saving source (ESS), the International Energy Agency has developed a global action plan to reduce energy consumption and costs worldwide, and the creation of Variable Frequency Drives to reduce energy consumption of asynchronous motors by $30-80 \%$ depending on load has become a priority issue [2].

In order to develop their economies without waste, the member states of the International Energy Agency have adopted state laws on proper energy management, efficient use, environmental protection, reduction of production costs and FC-based control of all electric motors to save energy [3-5].

The foundations of Azerbaijan's energy policy and the principles of its provision are reflected in the new oil strategy, which began with the signing of the "Contract of the Century" and has been implemented since 1994. In addition, Azerbaijan's transnational and domestic energy policy, measures taken in this area, the tasks implemented and other issues related to ensuring energy security are reflected in many official state documents adopted in the period of 2003-2014. The examples are the Law of the Republic of Azerbaijan "On Energy", the State Program "On the Use of Alternative and Renewable Energy Sources", the State Program "Development of the country's fuel and energy complex in 2005-2015", the Shah Deniz 2 natural gas project $[6,7]$.

Centrifugal pump, compressor and ventilation systems driven by a three-phase asynchronous motor are potential ESSs with great potential for energy savings. If asynchronous motors are controlled by FC, 30\% energy is saved, and if optimal control algorithms for electric motors are added, energy use will be more efficient and energy savings will grow by up to 60\% [8].

The huge number of asynchronous motors in all water systems of Azerbaijan, including artesian wells, shows that our country has great ESS, if they are equipped with energy-saving equipment (ESE), we can save a lot of energy.

Equipping all asynchronous motors used in Azerbaijan's water and other industries with modern ESE is a very large-scale potential ESS that requires great effort and organization.

If the implementation of this work is regulated by the support and laws of the government of Azerbaijan, great ESSs will be obtained in the near future and a great impetus to the development of the country's economy will be given. In addition, early diagnosis of the technical condition of the equipment will drastically reduce the number of "emergency" shutdowns, which will prevent a decline in productivity due to timely irrigation of the field.

Therefore, the identification of ESSs in the water management systems of Azerbaijan, the creation of ESEs, early diagnosis and equipping of all electric motors with ESEs, as well as the development of optimal control systems is a relevant issue that allows saving a lot of energy. 


\section{Problem statement}

The main purpose of the article is a comparative analysis of energy consumption in the direct and FC-based control of asynchronous motors with electric drive of artesian well pumps, principles of energy saving, calculation of energy savings, research of advantages and application of ESEs, creation of remote-controlled system that allows saving electric energy by regulating the rotation speed of asynchronous motor in artesian well pumping units.

\section{Solution}

Both electric motor and frequency converter set industrial machines and mechanisms in motion by converting the electricity entering their inputs into other types of energy. However, FCs have control advantages. FC-based ESEs save a lot of electricity.

3.1. The electric motor converts the fixed $(380 \mathrm{~V}, 50 \mathrm{~Hz})$ mains voltage supplied to it to the mechanical energy of the shaft by induction and drives the motor at a constant (maximum) speed.

FC controls the motor at a variable speed by converting the fixed $(380 \mathrm{~V}, 50 \mathrm{~Hz})$ mains voltage to a voltage and frequency that is regulated by PWM (Pulse-Width Modulation) [9].

The most common type of electric motors are asynchronous motors. When the rated load asynchronous motor is connected directly to the mains, the alternating $380 \mathrm{~V}$ voltage applied to its windings immediately tries to maximize the shaft speed. During heavy duty, the engine is overloaded 6-8 times and constantly running at maximum speed, which leads to energy loss.

$\mathrm{FC}$, on the other hand, transmits the voltage and frequency of the voltage to the motor via $\mathrm{PWM}$, gradually increasing by $\mathrm{V} / \mathrm{F}=\mathrm{CONST}$. During soft start, the engine is not loaded more than 1.5 times and saves energy by adjusting the speed to the maximum during operation.

Asynchronous motors are controlled by various types of FC in order to increase economic efficiency, minimize losses, protect the environment and save energy.

FC are mainly divided into PWM and DTC (Direct Torque Control) control groups. FC that belong to the general purpose PWM control group are widely used in HVAC systems, which are widely used in production.

In PWM control, both the width of the high-frequency PWM signals and the value and frequency of the operating voltage supplied to the motor are regulated by inverter controllers that control the motor at full speed.

The first reason PWM control saves energy is that the ratio of each pulse width (D), period (T) in the high-frequency signal flow varies in direct proportion to the control signal.

During the ON period of each pulse, electricity is transmitted to the engine, and during the OFF period, energy is taken from the engine. The "ON-OFF" switching feature of the pulse allows you to change the average power value and adjust the speed. Due to the high frequency (selected in the range of 4-12 kHz) of "ON-OFF" conversions (Modulation frequency), no fuzzy changes are felt in the load $[10,11]$.

In a fixed period $(\mathrm{T})$, it is possible to control energy by changing the width of each pulse ("ON" or "Duty Cycle"), i.e., by modulation. An increase in pulse width (energy increases) causes the speed to increase, and a decrease in width (energy decreases) causes the speed to decrease.

This means that by changing the width of a constant frequency pulse, energy is controlled and energy is saved.

The second reason PWM control saves energy is that the frequency converter controls the motor at constant speed Volt/Frequency $(\mathrm{V} / \mathrm{F}=380 / 50=7.6 \mathrm{~V} / \mathrm{Hz}=$ const) by varying the width of the constant-frequency pulse.

In steady VOLT/HERTZ control, the alternating voltage applied to the motor gradually increases with frequency (Fig. 1): 


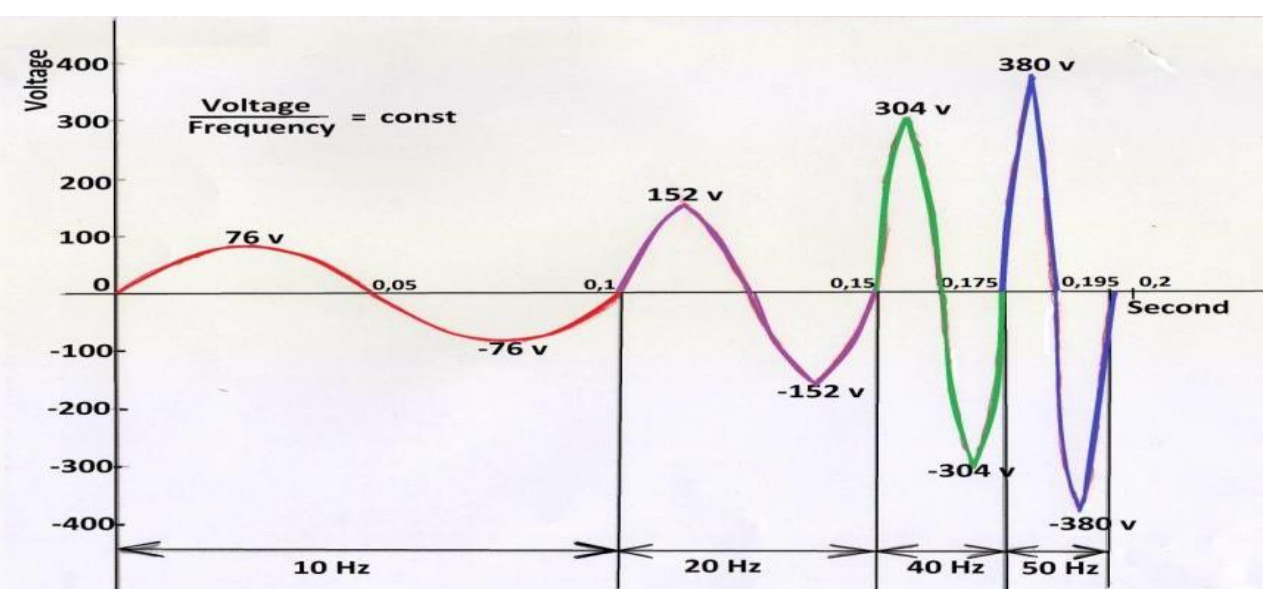

Fig. 1. Voltage and frequency variation in VOLT/HERTZ method control

To create an initial starting torque that allows the heavy load to be released from the ground, the FC applies a starting voltage to the engine for a short time (max 3 seconds). The value of the support voltage is in the range of $5-10 \%$ of the rated voltage of the engine. The cost of support tension can be adjusted.

The PWM-controlled FC mainly consists of a converter, a constant voltage capacitor and an inverter block (Fig. 2).

In a PWM-controlled FC device, a $50 \mathrm{~Hz}$ three-phase $380 \mathrm{~V}$ AC input voltage is converted to a constant voltage by entering the rectifier bridge circuit (converter) and accumulating at a high voltage capacitance $(\mathrm{C})$ to create a $380 \mathrm{Vx} 1.4=532 \mathrm{~V}$ fixed power supply. Then the output power inverter controlled by (4.0-12.0) $\mathrm{KHz}$ high-frequency PWM signals converts each phase of the motor to alternating voltage by connecting each phase of the motor to the negative or positive poles of a fixed power supply in a certain sequence by the law $\mathrm{V} / \mathrm{F}=\mathrm{CONST}$. Due to the inductance of the winding, the PWM signals are converted into fluctuating sinusoidal signals in the range of $0-50 \mathrm{~Hz}$ and drive the motor at all speeds. The engine load not exceeding 1.5 times during soft running and full speed adjustment during operation saves energy and reduces other losses.

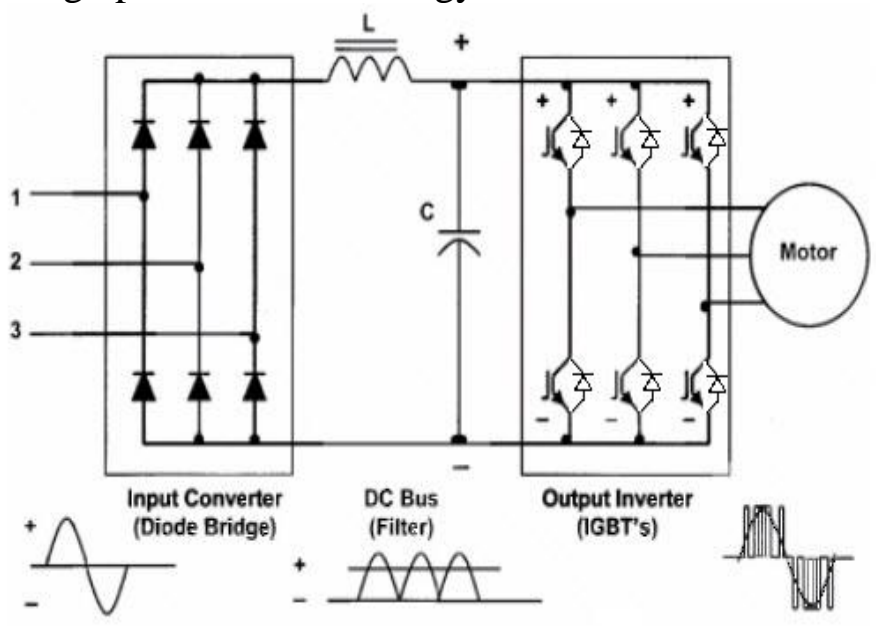

Fig. 2. Block diagram of a Frequency Converter device

In addition to smooth and efficient control, FC also has many additional sources of saving. For instance, saving energy, reducing mechanical impact, engine protection, etc.

FC-based control significantly saves electric energy because the motor does not receive more power than necessary from the mains. As a result of smooth control, the power grid is no longer overloaded and strong mechanical shocks do not occur. 
The efficiency of an asynchronous motor depends on the value of the PF-Power Factor. Low power factor means energy loss. The power factor of an induction motor is very small $\mathrm{PF}=0.2$ at no load, and reaches $\mathrm{PF}=0.85$ at maximum load. When an asynchronous motor operates below $50 \%$ of the rated load, the power factor decreases and the energy loss increases. When connected directly to the mains, the starting current of the motor is many times higher $[12,13]$.

FC-based control reduces losses and saves energy by increasing the engine's power factor. With FC, the power factor is $\mathrm{PF}=0.85$ at no load, and reaches $\mathrm{PF}=0.95$ at maximum load. In FC control, the increase in motor ignition current is low [14].

As a result of the improvement of control processes with the use of FC, the quality of products improves, the amount of waste is reduced, premature wear and tear of equipment is prevented, and their service life is extended.

There are many advantages to controlling asynchronous motors with FC. But the biggest advantage is that it saves the user's money by saving energy. The calculations that confirm these views can be found in full detail in [15-19].

3.2. The Institute of Control Systems of ANAS conducted a lot of research on the ways to identify ESS and save energy; together with Cybernetics SDB, it created a BPSCS device of the ESE group with early diagnostic capabilities, which has been successfully used in remote control of oil rigs in oil fields [20,21].

Detailed information on the technical parameters, control features, efficiency, installation and operation of the BPSCS device is given in the document "Explanatory text and operating guide for the BPSCS device" [22].

At present, BPSCS has been installed on more than 500 oil wells at various SOCAR oil fields and is equipped with a remote control system. According to experimental calculations, BPSCS control of asynchronous motors gives $30-60 \%$ energy savings, increases the service life of underground and surface equipment, and lightens the burden of human workers.

3.3. Based on all these positive results, the development of FC-based monitoring, diagnostics and control systems for subartesian well pumps is of great importance for the development and optimal management of water resources: automation of subartesian wells supplying agriculture and water to the population; increasing the efficiency of the water extraction process; reduction of electricity costs; improving the quality and safety of water supplied to consumers are among the most pressing and important issues. In order to carry out this work, the surface and underground equipment of subartesian wells is studied, technical requirements for automated remote control, early diagnosis and control system for early diagnosis and optimal control of their technical condition are formed and a block diagram of FC-based SCADA system is proposed.

The main surface equipment of subartesian wells usually consists of a power-supplying transformer substation, a submersible pump control device, a water intake and distributor, and a manually operated valve installed at the wellhead (Fig. 3).

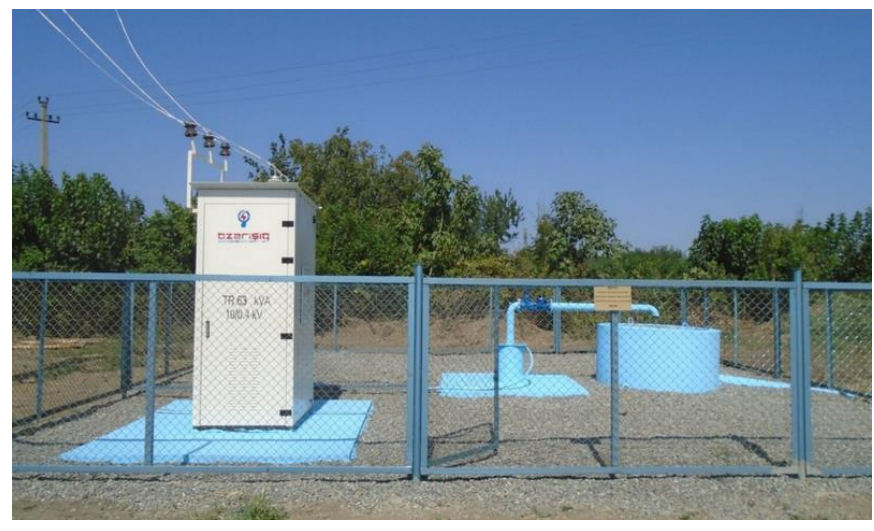

Fig. 3. Artesian wells surface equipment 
The main underground equipment of subartesian wells consists of a pumping station, a riser pipe, and a cable that supplies power to the pumping station (Fig. 4, 5).

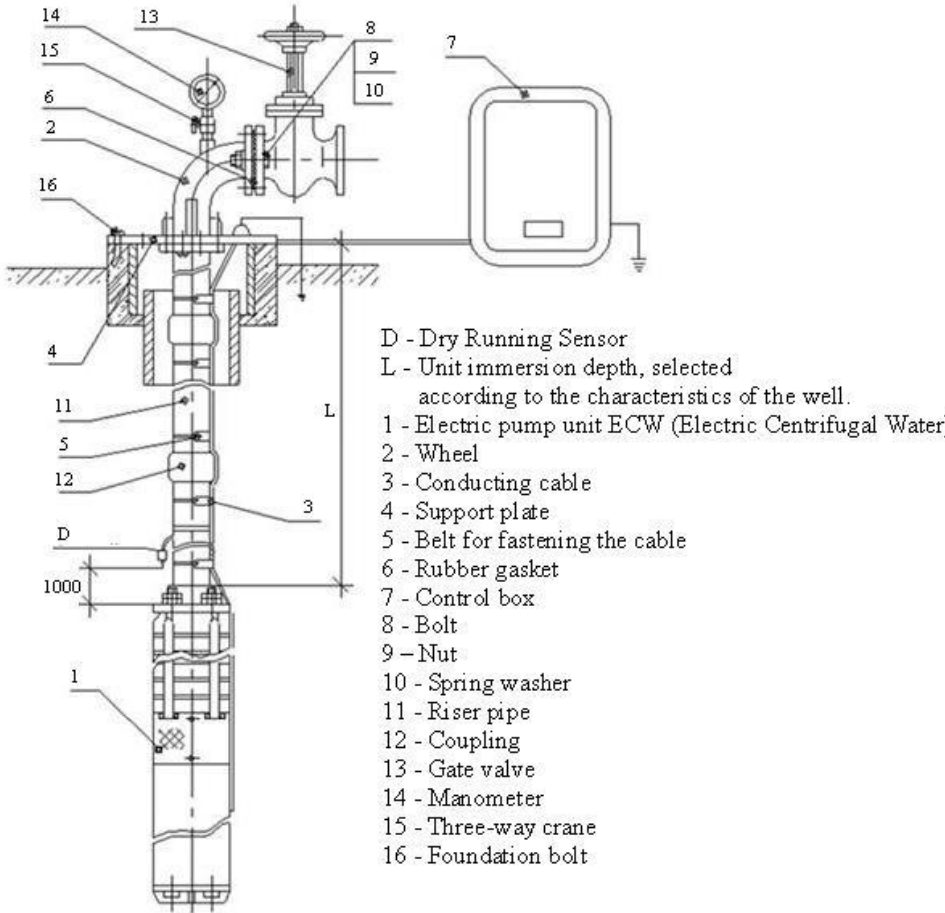

Fig. 4. Artesian wells surface and underground equipment installation scheme.

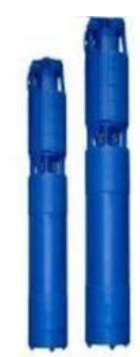

Fig. 5. ECW type pump

Electric centrifugal water pumps are vertical submersible devices designed to lift drinking water with a total salinity of not more than $1500 \mathrm{mg} / \mathrm{l}$ and a hydrogen index $(\mathrm{pH})$ of $6.5 . .9 .5$ from artesian wells. The temperature limit should be $25^{\circ} \mathrm{C}$, the mass fraction of mechanical impurities is $0.01 \%$, the content of chloride $350 \mathrm{mg} / \mathrm{l}$, sulfates up to $500 \mathrm{mg} / \mathrm{l}$, hydrogen sulfide up to $1.5 \mathrm{mg} / \mathrm{l}$. Water pumps are produced and branded in different sizes. Example: ETsV 12-160-100, here, ETsV is ECW - Electric Centrifugal Water, 12 - outer pipe diameter, inches, 160 - nominal yield, $\mathrm{m}^{3} / \mathrm{hour}$, 100 - nominal lifting height, $\mathrm{m}$ ). The pumping unit usually consists of a multi-stage centrifugal pump section and a submersible asynchronous electric motor connected by a rigid joint. The rotors of the pump and the electric motor are rotated by rubber-metal pads. A protective filter is installed at the inlet of the unit to protect the pump part from the ingress of large-sized mechanical contaminants. The electric motor is cooled by injected water.

Currently, ECW-type pumping units are connected to the $380 \mathrm{~V}$ three-phase network through various control and protection stations (e.g., SUZ, LOTSMAN, CASCADE, VYSOTA, etc.), which help protect the plant's electric motor from the following problems:

- overload;

- short circuit;

- phase loss and dry running.

The main feature of all artesian devices is the ability to start the pressure line with an open valve. This situation is easier to control, because in some cases the installation of the electric valve and its automation is not required.

Automated artesian well control system (AAWCS) is a SCADA system designed for automatic/local and remote control of artesian well equipment (AWE). The status and technological parameters of the AWE are monitored by the General or Regional Dispatch Centers (GDC or RDC) of the system via radio modem (frequency) or GSM (mobile) channel, data is received, analyzed, the 
speed of the pump motor is adjusted by selecting the optimal control mode depending on the water level and water consumption in the well.

AAWCS, the SCADA system of artesian wells, must fulfill the following functions:

- automatic/local and remote opening and connection of well equipment in accordance with the given algorithm;

- each element of all actuating mechanisms is opened and connected separately manually;

- control of network voltage in the area of the artesian well;

- oil temperature control at the transformer substation of the artesian well;

- pump outlet pressure control;

- control of static and dynamic water level in the well with piezometric sensor;

- "dry run" control if the well is equipped with a "dry" electrode sensor;

- thermal control in the kiosk (or in the pipe) and management of the heating system;

- position and control of electric valves (if any);

- control of flooding around the well, as well as safety and fire alarms;

- control of current consumed by pump electric motor;

- control of pump motor protection;

- recording of flow meter and electricity meter readings;

- storage of information on sensor parameters and operation of actuating mechanisms;

- data exchange with the dispatch center via the selected communication channel (cable, radio modem or GSM);

- transmission of current information on the status of sensors and actuating mechanisms at the request of the control center;

- alerting to emergency situations with sound and light signals;

- immediate transmission of emergency information to the control center and users via GSM channel.

The SCADA system of artesian wells consists of the following parts:

1. Artesian Well Smooth Control Station (AWSCS);

2. Monitoring, Measurement and Control (CMM) units of the artesian well;

3. Regional Dispatch Center (RDC);

4. General Dispatch Center (GDC).

Each AWE consists of two parts - the CMM units and the AWSCS device.

The block diagram of the new FC-based SCADA system, which meets all the requirements listed above, is given in Fig. 6. 


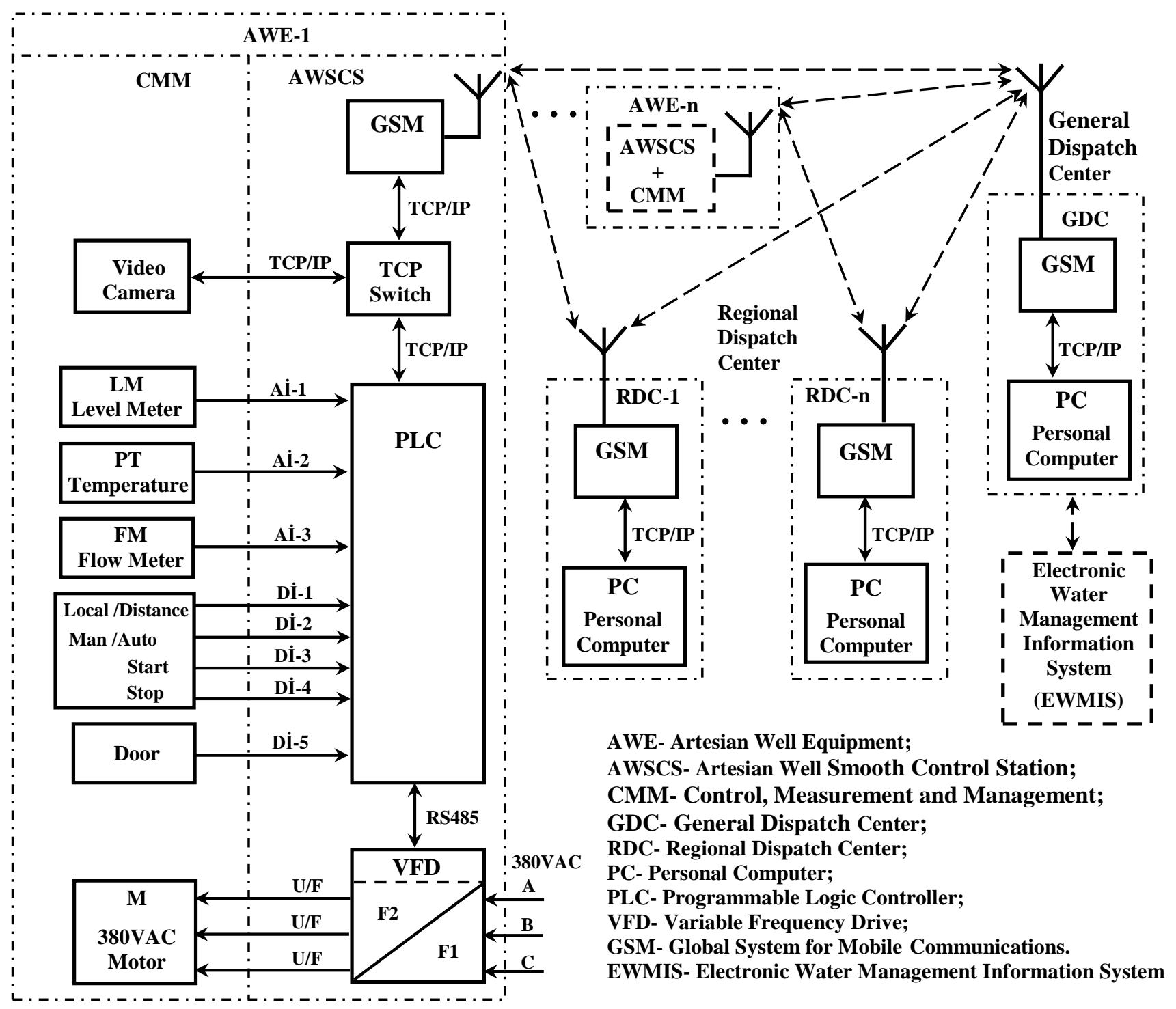

Fig. 6. Block diagram of SCADA system of artesian wells.

Designed for use in artesian wells, the FC-based AWSCS rig has great technical and economic advantages. For instance, it consists of a VFD (Variable Frequency Drive) capable of controlling the parameters of the well pump asynchronous motor and controlling the number of cycles of its shaft, PLC (Programmable Logic Controller) and GSM (Global System for Mobile Communications) means that receive and analyze signals from the control measurement and management units. The application of noise technologies allows for early diagnosis of technical failures that may occur in the surface and underground well equipment.

A comparative analysis of the operation of a water pump motor when controlled directly from the mains or via AWSCS is given below:

\section{When the motor is controlled directly from the mains:}

- No energy is saved;

- The power factor of the motor is small;

- Motor and equipment are not fully protected;

- Additional components and cable system are used excessively;

- As the starting current is 6-8 times higher, a more powerful motor and a cable with larger cross section are required; 
- Mechanical and electromagnetic losses are high;

- It is impossible to change the speed;

- Due to the rigidity of the transition processes in the mechanical parts, joints and mechanisms, the overhaul life is reduced, the equipment quickly ages and breaks down;

- Maintenance and repair costs increase.

\section{When the motor is controlled via AWSCS:}

- Depending on the nature of the load, more than 30-60\% energy is saved;

- The motor power factor is high;

- The engine is fully protected from short circuits, phase losses, overloads, overheating and dry runs;

- Additional components and cable system are rarely used because AWSCS is multifunctional;

- Due to the soft control feature, the starting current does not exceed 1.5 times, so there is no need for a very powerful motor and a cable of large cross section;

- The voltage on the windings of the motor gradually increases, no more magnetization occurs than given by the law $\mathrm{VFF}=\mathrm{CONST}$, no additional energy is required, even in the case of partial loading, mechanical and electromagnetic losses are reduced, energy is saved;

- The change in speed occurs instantly as a result of changing the frequency value;

- Due to the soft and smooth control, there are no sharp mechanical effects, the transition processes at the joints and mechanisms are not rigid, failures are reduced and the overhaul life is increased;

- Potential faults are detected in advance as a result of early diagnosis and accidents are prevented;

- Equipment service life increases, maintenance and repair costs decrease.

Let us take a look at how energy saving works in AWSCS-controlled operation by reducing the frequency:

\section{When the motor is controlled directly:}

- Motor power $\mathrm{Pm}=30 \mathrm{~kW}$;

- Motor maximum operating current Omax =66A;

- Motor max frequency Fmax $=50 \mathrm{~Hz}$;

- Mains voltage Vma $=380 \mathrm{VAC}$;

- Motor voltage $\mathrm{Vmo}=380 \mathrm{VAC}$;

- Motor power factor $\cos \phi=0.7$;

- Motor load percentage Pload $\%=80 \%$;

- Motor load current Cload $=52 \mathrm{~A}$.

Power required when the motor is controlled directly from the mains (Pd):

$\mathrm{Pd}=1.73 * 380 * 52 * 0.7=24 \mathrm{~kW}$.

When the motor is controlled by FC (operating frequency is set to $40 \mathrm{~Hz}$ ):

- Motor power $\mathrm{Pm}=30 \mathrm{~kW}$;

- Motor maximum operating current Omax =66A;

- Motor max frequency Fmax $=50 \mathrm{~Hz}$; 
- Motor operating frequency Fop $=40 \mathrm{~Hz}$;

- Mains voltage $\mathrm{Vma}=380 \mathrm{VAC}$;

- Motor voltage $\mathrm{Vmo}=380 \mathrm{VAC} / 50 \mathrm{~Hz} * 40 \mathrm{~Hz}=304 \mathrm{~V}$;

- Motor power factor $\cos \phi=0.7$;

- Motor load percentage Pload $\%=80 \%$;

- Motor load current Cload $=52 \mathrm{~A}$.

Power required when the motor is controlled by FC (Pfc):

Pfc $=1.73 * 304 * 52 * 0.7=19 \mathrm{~kW}$.

Percentage of energy savings: $\%=\{(\mathrm{Pd}-\mathrm{Pfc}) / \mathrm{Pd}\} * 100 \%=20 \%$.

Here, other parameters are kept constant to clearly see the energy savings as the value of the frequency is reduced. In fact, when the value of the frequency is reduced by $20 \%$, the percentage of energy savings is more than $30 \%$, depending on the load. If the optimal control algorithm is also applied, it can go up to $60 \%$.

\section{Conclusion}

1. A comparative analysis of the control of an artesian well water pump motor directly from the mains vs via AWSCS shows at least $20 \%$ energy savings.

2. The use of AWSCS allows for optimal control of the dynamic water level in the well, which is an additional source of energy savings.

3. Early diagnosis algorithms based on noise analysis technologies in AWSCS allow for timely prevention of malfunctions in the technical condition of surface and underground equipment.

4. An FC-based control, diagnostics and control system for artesian well pumps allows intervening (if necessary) in a prompt manner in the operation mode of any well connected to it.

\section{References}

[1] Jeff Colgan. "The International Energy Agency Challenges for the 21st Century", "Global Public Policy Institute", Paper No.6, Berlin, Germany, 2009.

[2] Paul Waide, Conrad Brunner. "Energy-efficiency policy opportunities for motor driven systems", France, 2011.

[3] "Text of the Energy Independence and Security Act of 2007 - GovTrack.us", Dec 18, 2007.

[4] Распоряжение Правительства РФ от 28.08.2003 N 1234-р, “Об энергетической стратегии России на период до 2030 года”. [In Russian: Order of the Government of the Russian Federation of 28.08.2003 N 1234-r, “On the energy strategy of Russia for the period up to 2030"].

[5] Распоряжение Правительства РФ от 13 ноябрь 2009 г. N 1715-р, “Энергетическая стратегия России на период до 2030 года". [In Russian: Order of the Government of the Russian Federation of November 13, 2009 N 1715-r, "Energy strategy of Russia for the period up to 2030"].

[6] E. Bağırzadə, “Azərbaycanin Enerji Ehtiyatlari və Onlardan İstifadənin Mövcud Vəziyyəti”, Bakı, 2014. [In Azerbaijani: E. Bagirzade, Energy resources of Azerbaijan and the current state of their use, Baku].

[7] “Azərbaycan Respublikasında alternativ və bərpa olunan enerji mənbələrindən istifadə olunması üzrə Dövlət Proqramı”nın təsdiq edilməsi haqqında Azərbaycan Respublikası Prezidentinin Sərəncamı, № 462, Bakı, 21 oktyabr 2004. [In Azerbaijani: Order of the President of the Republic of Azerbaijan on approval of the "State Program on use of alternative and renewable energy sources in the Republic of Azerbaijan”, № 462, Baku, October 21, 2004].

[8] Qiang Dong, "Evaluation of Economical Impact of Energy Optimization Functions in VFDs for Industrial Applications", Stockholm, Sweden 2011.

[9] "Facts Worth Knowing about Frequency Converters", Danfoss, December, 2014.

[10] PWM Techniques: A Pure Sine Wave Inverter, 2011. 
[11] "Applying Duty-Cycle Control to Save Power", AN865.

[12] Mauri Peltola, "Power Factor Improved by Variable Speed AC Drives".

[13] Stephen Prachyl, "Variable Frequency Drives and Energy Savings", USA, 2010.

[14] "High Efficiency Motor Protection", March, 1998, Rockwell International, USA.

[15] T.A. Oliyev, Q.A. Quluyev, As.H. Rzayev, Y.Q. Oliyev, M.H. Rezvan, Enerjiyə qənaət edən dəyişən tezlik çeviriciləri, Azərbaycan Milli Elmlər Akademiysının Xəbərləri, Fizika-Texnika və Riyaziyyat elmləri seriyası. 36 No.3 (2016) pp.87-102. [In Azerbaijani: T.A. Aliev, G.A. Guluyev, As.H. Rzayev, Y.G. Aliyev, M.H. Rezvan, Energy-saving variable frequency converters, Transactions of the Azerbaijan National Academy of Sciences, Series of Physical-Technical and Mathematical Sciences].

[16] TRM401_energy-savings-calculator_pump-and-fan-VFD_v2_18_14.

[17] "Energy Savings Estimator for Centrifugal Fans \& Pumps", Yaskawa, America, 2010

[18] Neetha John, Mohandas R, Suja Rajappan, "Energy Saving Mechanism Using Variable Frequency Drives", "International Journal of Emerging Technology and Advanced Engineering", March, 2013.

[19] "Variable Frequency Drives Energy Efficiency Reference Guid", Ceati International.

[20] Т.А. Алиев, Д.А. Искендеров, Г.А. Гулуев, Ас.Г. Рзаев, М.Г. Резван, "Результаты внедрения комплекса контроля, диагностики и управления для нефтяных скважин, эксплуатирующихся штанговыми глубинными насосами в нефтегазодобывающем управлении “Бибиэйбатнефть"”, Azərbaycan neft təsərrüfatı. No.6 (2014) pp.37-41. [In Russian: T.A. Aliev, D.A. Iskenderov, G.A. Guluyev, As.H. Rzayev, M.H. Rezvan, Results of the introduction of a complex of control, diagnostics and management for oil wells operated by sucker rod pumps in the Bibiheybatneft Oil and Gas Production Facility].

[21] Q.A. Quluyev, As.H. Rzayev, F.H. Paşayev, Y.Q. Oliyev, M. H. Rezvan, "Ştanqlı dərinlik nasos qurğusunun asinxron muhərriyi üçün dəyişən sürət intiqalı", Azərbaycan Milli Elmlər Akademiysının Xəbərləri, FizikaTexnika və Riyaziyyat elmləri seriyası. No.6 (2014) pp.140-148. [In Azerbaijani: G.A. Guluyev, As.H. Rzayev, F.H. Pashayev, Y.G. Aliyev, M.H. Rezvan, Variable speed drive for asynchronous motor of such rod pumping units, Transactions of the Azerbaijan National Academy of Sciences, Series of Physical-Technical and Mathematical Sciences].

[22] "İzahat mətni və texniki istismar qaydaları", DBF.2.100.001.2, AMEA Kibernetika XKB, Baki, 2014. [In Azerbaijani: Explanatory text and operating guide, DBF.2.100.001.2, Cybernetics SDB of ANAS, Baku]. 